Article

\title{
Synthesis and pervaporation performance of highly reproducible zeolite T membranes from clear solutions
}

\author{
ZHANG Xiaoliang, SONG Xin, QIU Lingfang, DING Minzheng, HU Na, ZHOU Rongfei, CHEN Xiangshu* \\ Jiangxi Inorganic Membrane Materials Engineering Research Centre, College of Chemistry and Chemical Engineering, Jiangxi Normal University, \\ Nanchang 330022, Jiangxi, China
}

\section{A R T I C L E I N F O}

\section{Article history:}

Received 5 September 2012

Accepted 12 October 2012

Published 20 March 2013

\section{Keywords:}

Zeolite T membrane

Reproducibility

Clear solution

Secondary growth

Pervaporation

\begin{abstract}
A B S T R A C T
Zeolite T membranes with very good permeation performance were successfully synthesized on porous mullite supports by the secondary growth method with homemade microsized seeds from clear solutions. The influence of synthesis parameters such as the molar ratios of $\mathrm{SiO}_{2} / \mathrm{Al}_{2} \mathrm{O}_{3}$ and $\mathrm{H}_{2} \mathrm{O} / \mathrm{SiO}_{2}$, alkalinity, synthesis temperature, and crystallization time on membrane growth and permeation performance was investigated systematically. It is found that these parameters strongly affect the zeolite $\mathrm{T}$ growth and pervaporation performance of the membranes. Under the optimized synthesis conditions of $1 \mathrm{SiO}_{2}: 0.015 \mathrm{Al}_{2} \mathrm{O}_{3}: 0.41\left(\mathrm{Na}_{2} \mathrm{O}+\mathrm{K}_{2} \mathrm{O}\right): 30 \mathrm{H}_{2} \mathrm{O}$, the crystallization time was shortened to $6 \mathrm{~h}$ at $423 \mathrm{~K}$ and a continuous and dense T-type zeolite layer as thin as $5 \mu \mathrm{m}$ formed on the surface of the support. It significantly improved the membrane density and permselective properties. A permeation flux and separation factor of $4.20 \mathrm{~kg} /\left(\mathrm{m}^{2} \cdot \mathrm{h}\right)$ and 7800 , respectively, were obtained with the as-synthesized membrane for $10 \mathrm{wt} \%$ water- $90 \mathrm{wt} \% \mathrm{i}$-propanol mixtures at 348 K. It also exhibited a very good pervaporation performance for water/ethanol mixtures separation. This high quality zeolite T membrane could be reproducibly prepared.
\end{abstract}

(C) 2013, Dalian Institute of Chemical Physics, Chinese Academy of Sciences. Published by Elsevier B.V. All rights reserved.

\section{Introduction}

Membrane separation is energy-efficient and many membranes have been developed for gas separation, catalytic membrane reactors, and pervaporation (PV) for liquid separation [1-3]. With a $\mathrm{Si} / \mathrm{Al}$ ratio of 3-4, the intergrowth of erionite and offretite, and an effective pore size of $0.36 \mathrm{~nm} \times 0.51 \mathrm{~nm}$, zeolite $\mathrm{T}$ has both hydrophilic and fairly high acid-resistant properties [4-22]. Therefore, zeolite $\mathrm{T}$ membranes have great potential for applications in gas separation and liquid separation by PV. In 2003, Cui et al. [4] first reported a zeolite T membrane synthesized on seeded mullite supports by hydrothermal synthesis, showing excellent $\mathrm{CO}_{2}$ separation performance. The mem- brane was as thick as $20 \mu \mathrm{m}$ and showed good PV performance for dehydrating separation of water/organics mixtures such as water/i-propanol mixtures and catalytic membrane reactors of esterification reactions [4-7]. Although some reports have described the preparation and permeation performance of zeolite $\mathrm{T}$ membranes, the membrane synthesis precursor is mostly a milk-like aluminosilicate gel with a molar ratio of $\mathrm{H}_{2} \mathrm{O} / \mathrm{SiO}_{2}$ of 14-16 [4-11] and the synthesis time is as long as $30 \mathrm{~h}$. Thus, the formed membrane is as thick as $10-20 \mu \mathrm{m}$, which will decrease its permeate flux [4-11]. Recently, we reported the preparation of zeolite $\mathrm{T}$ membranes using a clear aluminosilicate solution with the molar ratio of $\mathrm{H}_{2} \mathrm{O} / \mathrm{SiO}_{2}$ of $25[12,13]$ or using a two-stage temperature-varying synthesis method with

\footnotetext{
* Corresponding author. Tel: +86-791-88120533; Fax: +86-791-88120843; E-mail: cxs66cn@jxnu.edu.cn This work was supported by the National Natural Science Foundation of China (20966003, 21106059), the National High Technology Research and Development Program of China (863 Program, 2012AA03A609), Jiangxi Provincial Department of Science and Technology (2010BGA01200, 2010GQH0068, 20122BAB203018), and Jiangxi Provincial Department of Education (GJJ11377). 
microsized seeds [15]. We also reported the fast synthesis of zeolite T membranes within only $6 \mathrm{~h}$ in a fluoride medium [14], showing high selectivity for water/organics mixtures by PV. However, to our best knowledge, there are few reports on the details of the synthesis of zeolite T membranes from clear solutions. The effects of synthesis parameters on membrane growth and PV properties are not clearly understood. Moreover, the poor reproducibility of zeolite membranes arouses attention because it will raise the preparation cost and influence the large-scale application of zeolite membranes.

In the present study, a well-intergrown zeolite $\mathrm{T}$ membrane with enhanced permeation properties was rapidly hydrothermally synthesized from clear solutions. The influence of synthesis parameters on membrane growth and permeation performance was investigated systematically. The as-synthesized membranes displayed a high PV performance for water/organics mixtures separation and high reproducibility.

\section{Experimental}

\subsection{Membrane synthesis}

Zeolite $\mathrm{T}$ membranes were synthesized by the seeded secondary growth method on $100 \mathrm{~mm}$ long porous mullite tubes (Nikkato Corp.). The tubes had an outer diameter of $12 \mathrm{~mm}$, a wall thickness of $1.5 \mathrm{~mm}$, an average pore size of $1.3 \mu \mathrm{m}$, and a porosity of $\sim 43 \%$. The tubes were polished with SiC sandpaper, washed in deionized water in an ultrasonic bath, and then dried in an oven at $373 \mathrm{~K}$ for $6 \mathrm{~h}$. Before the hydrothermal synthesis, the support tubes were rub-coated with a water slurry of zeolite $\mathrm{T}$ powder, which was described elsewhere [13-15]. Microsized zeolite seeds were prepared from aluminosilicate gel with a molar composition of $1 \mathrm{SiO}_{2}: 0.055 \mathrm{Al}_{2} \mathrm{O}_{3}: 0.24 \mathrm{Na}_{2} \mathrm{O}$ : $0.08 \mathrm{~K}_{2} \mathrm{O}: 12 \mathrm{H}_{2} \mathrm{O}$ [15]. The gel was mixed with precipitated silica (98 wt\% $\mathrm{SiO}_{2}$, Degussa VN3), $\mathrm{Al}(\mathrm{OH})_{3}$ (Wako Pure Chemical), $\mathrm{NaOH}$ (Aldrich), KOH (Aldrich), and distilled water, followed by aging at room temperature for $12 \mathrm{~h}$ and crystallization at $373 \mathrm{~K}$ for $96 \mathrm{~h}$. The products were recovered by centrifugation, washed with hot water, and dried at $393 \mathrm{~K}$ overnight. The seeds had a rod-like shape with an average size of $2.5 \mu \mathrm{m} \times 0.5$ $\mu \mathrm{m}[15]$.

The clear synthesis solutions were prepared by mixing colloidal silica (TM-40, $40 \mathrm{wt} \% \mathrm{SiO}_{2}$, Aldrich), $\mathrm{Al}(\mathrm{OH})_{3}, \mathrm{NaOH}$, $\mathrm{KOH}$, and distilled water, followed by vigorous stirring at room temperature for $1 \mathrm{~h}$. The molar composition of the resulting solutions was $1 \mathrm{SiO}_{2}:(0.0005-0.020) \mathrm{Al}_{2} \mathrm{O}_{3}:(0.29-0.44)\left(\mathrm{Na}_{2} \mathrm{O}+\right.$ $\mathrm{K}_{2} \mathrm{O}$ ):(20-200) $\mathrm{H}_{2} \mathrm{O}$ (with $n(\mathrm{Na}) / n(\mathrm{~K})=3$ ). Then the seeded tube was vertically placed in a stainless steel autoclave filled with synthesis solution and the crystallization process was carried out at synthesis temperatures of 373 to $448 \mathrm{~K}$ for a given time. After crystallization, the membrane sample was taken out, washed carefully with hot deionized water, and dried.

\subsection{Pervaporation measurements}

Pervaporation tests were essentially the same as those de- scribed in our previous publications [12-15]. The inside of the membrane tube was evacuated by a vacuum pump. The permeate vapor was collected by a cold trap cooled with liquid nitrogen. The downstream pressure was kept below $20 \mathrm{~Pa}$. The compositions of feed and permeate were analyzed by a gas chromatograph (GC, GC-14C, Shimadzu) equipped with a $3 \mathrm{~m}$ column packed with Polarpack Q poly(ethylene glycol)-1000. The permeation flux was calculated by weighing the condensed permeate. Based on the experimental data, the PV performance of the membrane can be characterized in terms of permeation flux $\left(J, \mathrm{~kg} /\left(\mathrm{m}^{2} \cdot \mathrm{h}\right)\right)$ and separation factor $(\alpha)$ as shown below:

$$
\begin{gathered}
J=m / A t \\
\alpha_{\mathrm{w} / \mathrm{o}}=\left(y_{\mathrm{w}} / y_{\mathrm{o}}\right) /\left(x_{\mathrm{w}} / x_{0}\right)
\end{gathered}
$$

where $m$ is the mass of permeate collected over a period time $(t), A$ is the effective membrane area for permeation, and $x_{\mathrm{w}}, x_{0}$, $y_{\mathrm{w}}$, and $y_{\mathrm{o}}$ denote the mass fractions of water and organics at the feed and permeate sides, respectively. Unless otherwise noted, the pervaporation tests were carried out with $10 \mathrm{wt} \%$ water-90 wt $\% i$-propanol mixtures at $348 \mathrm{~K}$.

\subsection{Characterization}

The crystal structure of zeolite seeds and as-synthesized membranes were characterized by X-ray diffraction (XRD, Ultima IV, Rigaku) with $\mathrm{Cu} K_{\alpha}$ radiation at $40 \mathrm{kV}$ and $120 \mathrm{~mA}$. The morphology and thickness of the zeolite membranes were examined using a scanning electron microscopy (SEM, VEGA3 SBU, Tescan).

\section{Results and discussion}

\subsection{Effect of $\mathrm{SiO}_{2} / \mathrm{Al}_{2} \mathrm{O}_{3}$ ratio}

Figure 1 shows the PV performance of zeolite T membranes prepared in the synthesis solutions of $1 \mathrm{SiO}_{2}:(0.0005-0.020)$ $\mathrm{Al}_{2} \mathrm{O}_{3}: 0.35\left(\mathrm{Na}_{2} \mathrm{O}+\mathrm{K}_{2} \mathrm{O}\right): 30 \mathrm{H}_{2} \mathrm{O}$ at $423 \mathrm{~K}$ for $18 \mathrm{~h}$. It can be seen that the $\mathrm{SiO}_{2} / \mathrm{Al}_{2} \mathrm{O}_{3}$ ratio, which ranged from 50 to 2000, strongly influenced the PV performance. The permeation flux greatly increased with increasing $\mathrm{SiO}_{2} / \mathrm{Al}_{2} \mathrm{O}_{3}$ ratio when the ratio was less than 66.7 , whereas the flux rapidly decreased when the ratio was over 66.7. Moreover, the separation factor

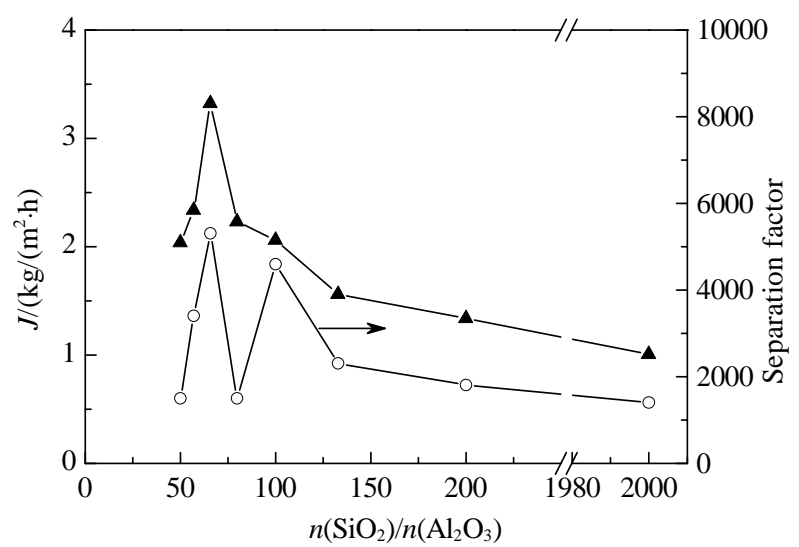

Fig. 1. Effect of $\mathrm{SiO}_{2} / \mathrm{Al}_{2} \mathrm{O}_{3}$ ratio on the $\mathrm{PV}$ performance of the as-synthesized membranes. 
showed a similar trend. When the $\mathrm{SiO}_{2} / \mathrm{Al}_{2} \mathrm{O}_{3}$ ratio was 66.7 (i.e. $\mathrm{Al}_{2} \mathrm{O}_{3} / \mathrm{SiO}_{2}$ ratio of 0.015 ), the highest flux and separation factor of these membranes were achieved at $3.32 \mathrm{~kg} /\left(\mathrm{m}^{2} \cdot \mathrm{h}\right)$ and 5300, respectively. According to the PV performance, it can be concluded that the best ratio of $\mathrm{SiO}_{2} / \mathrm{Al}_{2} \mathrm{O}_{3}$ is 66.7 under these synthesis conditions, which is the same as in our previous investigations $[12,13]$.

\subsection{Effect of alkalinity}

Commonly, the relative alkalinity $\left(n\left(\mathrm{OH}^{-}\right) / n\left(\mathrm{SiO}_{2}\right)\right)$ is an important parameter for zeolite growth, because it will influence the crystallinity and structure stability of zeolites. It is well known that alkali cations in their hydroxide forms usually play a structure-directing role and as well provide the high alkalinity needed for the T-type zeolite crystallization. Figure 2 shows the dependence of the PV performance on alkalinity for zeolite $\mathrm{T}$ membranes prepared in the synthesis solutions of $1 \mathrm{SiO}_{2}: 0.015 \mathrm{Al}_{2} \mathrm{O}_{3}:(0.29-0.44)\left(\mathrm{Na}_{2} \mathrm{O}+\mathrm{K}_{2} \mathrm{O}\right): 30 \mathrm{H}_{2} \mathrm{O}$ at $423 \mathrm{~K}$. As can be seen in Fig. 2, the permeation flux and the selectivity increased with the alkalinity until the alkalinity reached 0.82 . However, a sharp decrease of separation factor from 7800 to 800 was observed when the alkalinity was above 0.82 . It suggests that alkalinity had a very strong influence on membrane growth and PV performance under these synthesis conditions.

As shown in Fig. 3, the XRD patterns of these membranes displayed the peaks of both zeolite $\mathrm{T}$ and the mullite support, and no peaks of other zeolite phases were observed for all samples. It indicates that all the membranes were formed on the support surface and no phase transformation occurred during the crystallization stage. The relative intensity of the main characteristic peaks of zeolite $\mathrm{T}\left(2 \theta=7.7^{\circ}, 13.3^{\circ}, 20.4^{\circ}\right.$, $23.6^{\circ}, 24.8^{\circ}, 28.3^{\circ}$, and $31.4^{\circ}$ [16]) increased greatly with increasing alkalinity, demonstrating the high crystallinity of these membranes. However, the membrane prepared at the alkalinity of 0.88 showed obviously stronger peaks of the mullite support than that of zeolite $\mathrm{T}$, especially at $2 \theta=30.97^{\circ}$, demonstrating that the membrane was not compact and thus showing poor selectivity as can be seen in Fig. 2. Generally, with increasing alkalinity, the concentration of soluble silicate species in the synthesis solution will increase, thus increasing the solubility of

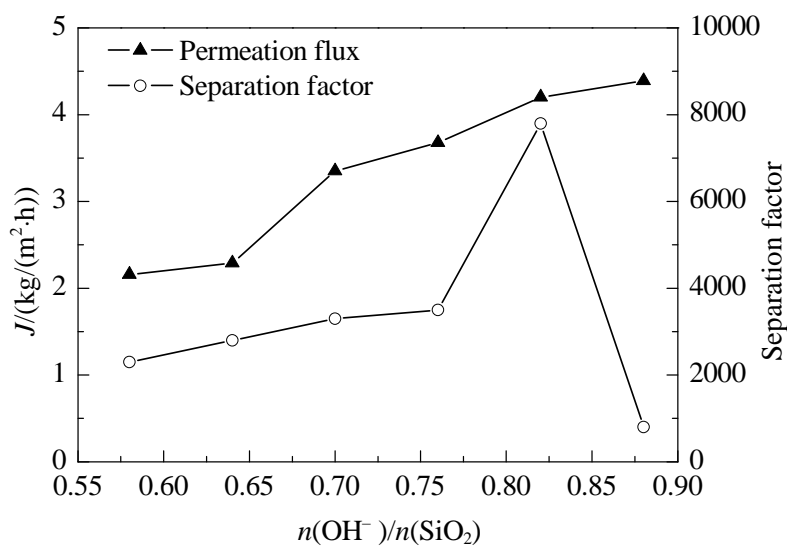

Fig. 2. Effect of alkalinity on the PV performance of the as-synthesized membranes.

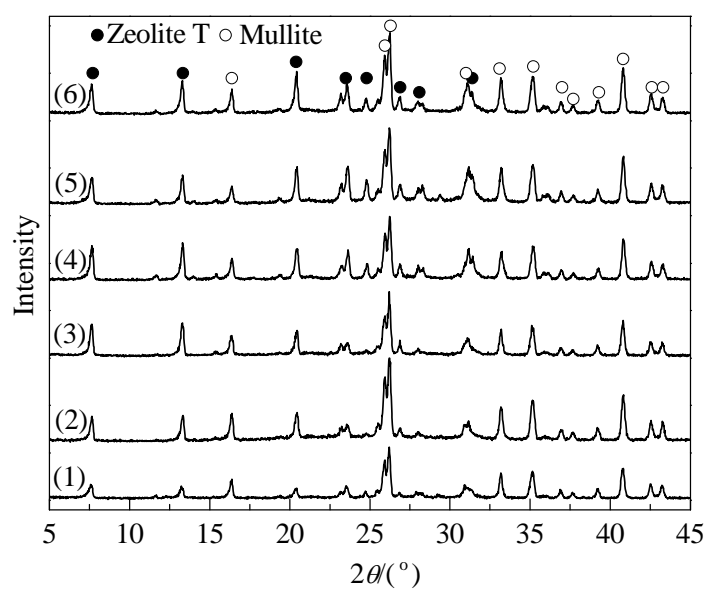

Fig. 3. XRD patterns of zeolite $\mathrm{T}$ membranes prepared with different alkalinity of $n\left(\mathrm{OH}^{-}\right) / n\left(\mathrm{SiO}_{2}\right)$ as $0.58(1), 0.64$ (2), 0.70 (3), $0.76(4), 0.82$ (5), and $0.88(6)$.

$\mathrm{Si}$ and $\mathrm{Al}$ sources, decreasing the polymerization degree of silicate anions and accelerating the polymerization of polysilicate and aluminate anions [23]. Consequently, the increase of alkalinity will shorten the induction and nucleation periods and promote the crystallization of zeolites, resulting in denser zeolite membranes [19-23]. Therefore, the crystallinity of as-synthesized membranes increases first during the experiments in which alkalinity increases within a constant period, showing an increase of PV performance. However, at higher alkalinity, the synthesized zeolite crystals will dissolve again and lead to poor density, thus reducing the PV properties of the zeolite T membranes.

\subsection{Effects of $\mathrm{H}_{2} \mathrm{O} / \mathrm{SiO}_{2}$ ratio, synthesis temperature, and crystallization time}

Table 1 shows the PV performance of zeolite membranes prepared with different $\mathrm{H}_{2} \mathrm{O} / \mathrm{SiO}_{2}$ ratios. All the samples had approximately the same thickness and were synthesized with molar solutions of $1 \mathrm{SiO}_{2}: 0.015 \mathrm{Al}_{2} \mathrm{O}_{3}: 0.41\left(\mathrm{Na}_{2} \mathrm{O}+\mathrm{K}_{2} \mathrm{O}\right):(20-$ $200) \mathrm{H}_{2} \mathrm{O}$ at $423 \mathrm{~K}$ for $4-120 \mathrm{~h}$. Figures 4 and 5 show the XRD patterns and SEM images of these zeolite membranes, respectively. As shown in Table 1, the relatively concentrated or dilute solutions were not suitable for synthesizing zeolite $\mathrm{T}$ mem-

Table 1

Effects of $\mathrm{H}_{2} \mathrm{O} / \mathrm{SiO}_{2}$ ratio, synthesis temperature, and crystallization time on the $\mathrm{PV}$ performance.

\begin{tabular}{lccrcr}
\hline Sample & $\begin{array}{c}n\left(\mathrm{H}_{2} \mathrm{O}\right) / \\
n\left(\mathrm{SiO}_{2}\right)\end{array}$ & $\begin{array}{c}\text { Temperature } \\
(\mathrm{K})\end{array}$ & $\begin{array}{c}\text { Time } \\
(\mathrm{h})\end{array}$ & $\begin{array}{c}J / \\
\left(\mathrm{kg} /\left(\mathrm{m}^{2} \cdot \mathrm{h}\right)\right)\end{array}$ & $\alpha$ \\
\hline T1 & 20 & 423 & 4 & 1.78 & 1300 \\
T2 & 30 & 423 & 6 & 4.20 & 7800 \\
T3 & 40 & 423 & 12 & 3.45 & 3400 \\
T4 & 50 & 423 & 18 & 3.50 & 2800 \\
T5 & 80 & 423 & 36 & 2.45 & 1600 \\
T6 & 100 & 423 & 80 & 2.65 & 1000 \\
T7 & 200 & 423 & 120 & 3.24 & 970 \\
T8 & 30 & 373 & 24 & 2.34 & 700 \\
T9 & 30 & 398 & 12 & 3.56 & 2300 \\
T10 & 30 & 448 & 4 & 4.40 & 1800 \\
\hline
\end{tabular}




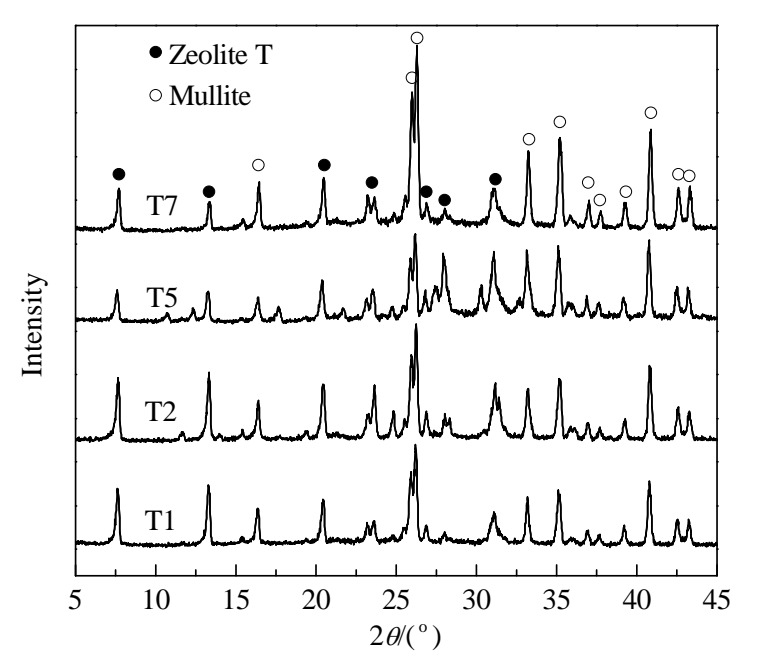

Fig. 4. XRD patterns of zeolite $\mathrm{T}$ membranes prepared with different $\mathrm{H}_{2} \mathrm{O} / \mathrm{SiO}_{2}$ ratios as shown in Table 1.

branes with high PV performance. In general, increasing the water content in the synthesis solution leads to a decrease of hydroxyl ions concentration in the solution or alkalinity, thus resulting in a monotonic decrease of zeolite growth and crystallinity [21,22]. Matin et al. [21] found a decrease in the zeolite $\mathrm{T}$ content of the crystal product samples with increasing water content in the solutions. In this work, the membrane T7, prepared with $\mathrm{H}_{2} \mathrm{O} / \mathrm{SiO}_{2}$ ratio of 200 by hydrothermal treatment for $120 \mathrm{~h}$, showed the poorest selectivity. Although the main characteristic peaks of zeolite $\mathrm{T}$ appeared with weak intensity for membrane T7 as can be seen in Fig. 4, a well-intergrown zeolite $\mathrm{T}$ layer did not form on the seeded support as shown in Fig. 5(g) and (h). On the other hand, as shown in Fig. 5(a) and (b), a fully continuous dense zeolite $\mathrm{T}$ crystal layer also could not grow on the support from the synthesis solution with an $\mathrm{H}_{2} \mathrm{O} / \mathrm{SiO}_{2}$ ratio as low as 20 (membrane T1). This might be due to crystals agglomerating quickly under such synthesis conditions and cause the emergence of some defects, resulting in poor separation performance as illustrated in Table 1. As shown in Fig. 5(c) and (d), when the $\mathrm{H}_{2} \mathrm{O} / \mathrm{SiO}_{2}$ ratio was 30 during the crystallization process, the surface of the mullite support was fully covered with rod-like zeolite T crystals, leading to a higher crystallinity of membrane T2 (see Fig. 4). The continuous, intergrown layer was only about $5 \mu \mathrm{m}$ thin and without defect, which resulted in the highest PV performance for membrane $\mathrm{T} 2$ as shown in Table 1, when compared to the other membranes.

Table 1 also shows the PV performance of zeolite T membranes prepared at different synthesis temperatures from 373 to $448 \mathrm{~K}$. All the samples were synthesized in the same molar composition synthesis solution. As can be seen in Table 1, the growth rate of zeolite $\mathrm{T}$ crystals was too low to form a compact crystal layer on the seeded support at $373 \mathrm{~K}$. Even with the crystallization time prolonged to $24 \mathrm{~h}$, membrane T8 still showed poor permselectivity. When the synthesis temperature was increased to $448 \mathrm{~K}$ for $4 \mathrm{~h}$ during the crystallization process, membrane T10 also exhibited a low separation factor of 1800. This suggests that the crystal growth rate at higher temperatures was faster than those of other membranes and it was difficult to form a dense zeolite layer on the seeded support surface under such synthesis conditions.

\subsection{Reproducibility of membrane synthesis}

High reproducibility of zeolite membranes with high permeation performance is an important aspect for potential applications. Therefore, the reproducibility of the zeolite T membranes prepared from clear solutions was tested through PV experiments in this work. Five series of ten parallel tubes of zeolite $\mathrm{T}$ membranes were prepared on seeded mullite supports under the same optimized conditions (as membrane T2). All the samples were characterized by SEM and XRD. It showed that these membranes were defect-free and purely crystalline with a typical T-type zeolite structure without other zeolite phases (not shown in this work). As shown in Fig. 6, these
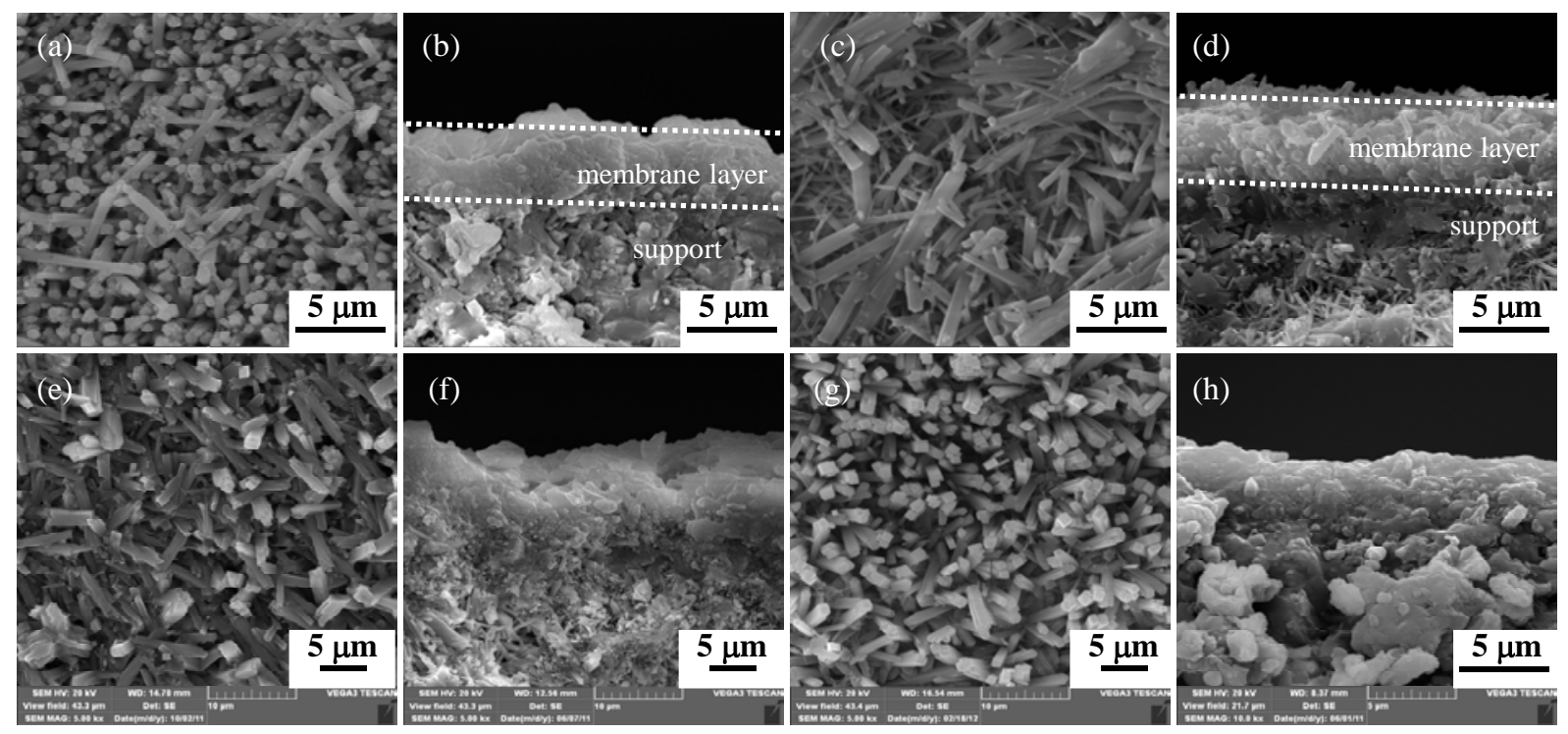

Fig. 5. SEM surface (a, c, e, g) and cross-sectional (b, d, f, h) images of zeolite T membranes. (a, b) T1; (c, d) T2; (e, f) T5; (g, h) T7. 
Table 2

PV performance of zeolite T membranes in separation of $10 \mathrm{wt} \%$ water- $90 \mathrm{wt} \%$ organics mixtures at $348 \mathrm{~K}$ in this work and in the literature.

\begin{tabular}{|c|c|c|c|c|c|c|c|c|c|}
\hline \multirow{2}{*}{ Support } & \multicolumn{5}{|c|}{ Synthesis conditions } & \multirow{2}{*}{$\begin{array}{c}\text { Separation } \\
\text { system }\end{array}$} & \multicolumn{2}{|c|}{ PV performance } & \multirow{2}{*}{ Ref. } \\
\hline & $n\left(\mathrm{Al}_{2} \mathrm{O}_{3}\right) / n\left(\mathrm{SiO}_{2}\right)$ & $n\left(\mathrm{OH}^{-}\right) / n\left(\mathrm{SiO}_{2}\right)$ & $n\left(\mathrm{H}_{2} \mathrm{O}\right) / n\left(\mathrm{SiO}_{2}\right)$ & Temperature (K) & Time (h) & & $J /\left(\mathrm{kg} /\left(\mathrm{m}^{2} \cdot \mathrm{h}\right)\right)$ & $\alpha$ & \\
\hline \multirow{2}{*}{ Mullite } & 0.050 & 0.70 & 14 & 373 & 30 & $\mathrm{H}_{2} \mathrm{O} / \mathrm{IPA}$ & 2.20 & 8900 & [6] \\
\hline & & & & & & $\mathrm{H}_{2} \mathrm{O} / \mathrm{EtOH}$ & 1.10 & 900 & \\
\hline \multirow[t]{2}{*}{$\alpha-\mathrm{Al}_{2} \mathrm{O}_{3} *$} & 0.050 & 0.70 & 14 & $373+413$ & $8+1$ & $\mathrm{H}_{2} \mathrm{O} / \mathrm{IPA}$ & 2.15 & 10000 & [11] \\
\hline & & & & & & $\mathrm{H}_{2} \mathrm{O} / \mathrm{EtOH}$ & 1.77 & 1116 & \\
\hline \multirow[t]{2}{*}{ Mullite } & 0.015 & 0.66 & 25 & 423 & 35 & $\mathrm{H}_{2} \mathrm{O} / \mathrm{IPA}$ & 2.52 & 10000 & [12] \\
\hline & & & & & & $\mathrm{H}_{2} \mathrm{O} / \mathrm{EtOH}$ & 1.16 & 2800 & \\
\hline \multirow[t]{2}{*}{ Mullite } & 0.015 & 0.82 & 30 & 423 & 6 & $\mathrm{H}_{2} \mathrm{O} / \mathrm{IPA}$ & 4.20 & 7800 & this work \\
\hline & & & & & & $\mathrm{H}_{2} \mathrm{O} / \mathrm{EtOH}$ & 2.70 & 3800 & \\
\hline
\end{tabular}

IPA: $i$-propanol; EtOH: ethanol. * Conventional hydrothermal synthesis at $373 \mathrm{~K}$ for $8 \mathrm{~h}$ followed by microwave heating at $413 \mathrm{~K}$ for $1 \mathrm{~h}$; PV test temperature was $338 \mathrm{~K}$ in Ref. [11].

membranes exhibited high PV performance towards water/i-propanol mixtures at $348 \mathrm{~K}$. The average values of permeation flux and permeated water content on the permeate side were $(4.15 \pm 0.05) \mathrm{kg} /\left(\mathrm{m}^{2} \cdot \mathrm{h}\right)$ and $99.86 \% \pm 0.02 \%$ (corresponding to an average separation factor of about 7000), respectively. According to the experimental data, the relative standard deviation (RSD) values of the permeation flux and permeated water content on the permeate side were calculated to be only $2.30 \%$ and less than $0.01 \%$, respectively, demonstrating the high reproducibility of zeolite $\mathrm{T}$ membranes in this work. Moreover, as illustrated in Table 2, the membrane also exhibited high PV performance for $10 \mathrm{wt} \%$ water- $90 \mathrm{wt} \%$ ethanol mixtures at $348 \mathrm{~K}$. A permeation flux of $2.70 \mathrm{~kg} /\left(\mathrm{m}^{2} \cdot \mathrm{h}\right)$ and separation factor of 3800 , respectively, were obtained for the membrane.

\subsection{Comparison of pervaporation performance}

The PV properties and the corresponding synthesis parameters of zeolite $\mathrm{T}$ membranes of this work are listed in Table 2 and compared to those from other reports $[6,11,12]$. As can be seen in Table 2, the PV performances of zeolite $\mathrm{T}$ membranes of this study were higher than those reported in the literatures. This may have been caused by the much thinner membrane thickness $(5 \mu \mathrm{m})$ compared to those of the membranes (about $10-20 \mu \mathrm{m})$ reported in references [6,11,12]. Moreover, it is worth noting that the crystallization time was much shorter $(6$ h) than those reported in the literatures $(9-35 \mathrm{~h})$, even com-

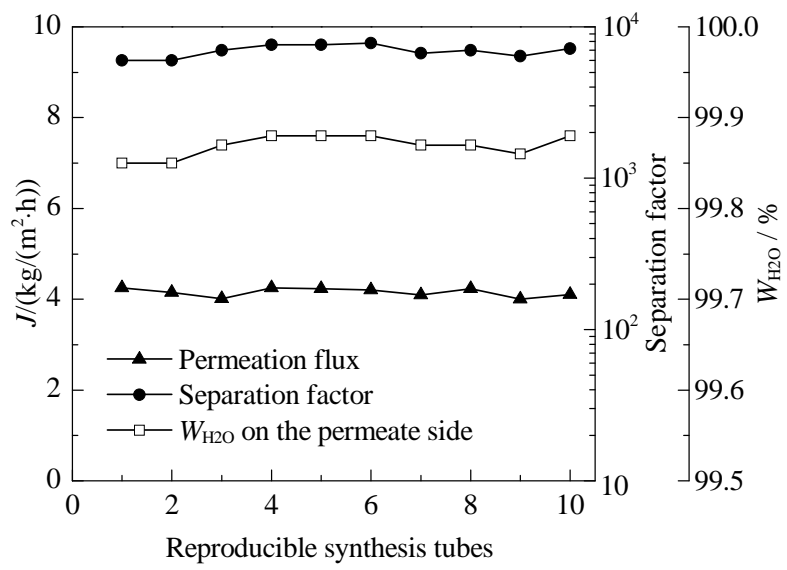

Fig. 6. PV performance of reproduced zeolite T membranes. pared to the one using rapid microwave treatment [11]. Even though the permeation properties of zeolite membranes from different labs are often difficult to compare because of the different experimental conditions including support properties, raw material sources, and synthesis methods, it can be said that it was practicable to rapidly synthesize zeolite $T$ membranes with enhanced permeation properties from clear solutions in this work.

\section{Conclusions}

Highly reproducible zeolite $\mathrm{T}$ membranes with enhanced pervaporation properties were rapidly synthesized from clear solutions. The synthesis parameters, especially the alkalinity of the clear synthesis solutions, strongly affect the membrane growth and pervaporation performance. Under the optimized synthesis conditions, the as-synthesized zeolite $\mathrm{T}$ membranes displayed high pervaporation performance for water/organics mixtures. The development of such zeolite $\mathrm{T}$ membranes could open up more opportunities for application in the dehydration process of organic liquids. In follow-up work, the crystallization mechanisms in clear solutions at such short times will be further investigated and $\mathrm{CO}_{2}$ permselectivity of such zeolite $\mathrm{T}$ membranes will be tested.

\section{References}

[1] Drioli E, Fontananova E, Bonchio M, Carraro M, Gardan M, Scorrano G. Chin J Catal (催化学报), 2008, 29: 1152

[2] Zhang X L, Wang W P, Xiong G X, Yang W Sh. Chin J Catal (张小亮, 王卫平, 熊国兴, 杨维慎. 催化学报), 2010, 31: 1049

[3] Li X M, Wang Zh B, Zheng J, Shao Sh Q, Wang Y Ch, Yan Y Sh. Chin J Catal (李显明, 王正宝, 郑洁, 郡世群, 王胤超, 严玉山. 催化学 报), 2011, 32: 217

[4] Cui Y, Kita H, Okamoto K I. Chem Commun, 2003: 2154

[5] Cui Y, Kita H, Okamoto K I. J Mater Chem, 2004, 14: 924

[6] Cui Y, Kita H, Okamoto K I. J Membr Sci, 2004, 236: 17

[7] Kondo M, Kita H. J Membr Sci, 2010, 361: 223

[8] Mirfendereski M, Sadrzadeh M, Mohammadi T. Int J Greenhouse Gas Control, 2008, 2: 531

[9] Mirfendereski S M, Mazaheri T, Sadrzadeh M, Mohammadi T. Sep Purif Technol, 2008, 61: 317

[10] Zhou H, Li Y Sh, Zhu G Q, Liu J, Lin L W, Yang W Sh. Chin J Catal (周 汉, 李砚硕, 朱广奇, 刘杰, 林励吾, 杨维慎. 催化学报), 2008, 29: 592 


\section{Graphical Abstract}

Chin. J. Catal., 2013, 34: 542-547 doi: 10.1016/S1872-2067(11)60478-6

Synthesis and pervaporation performance of highly reproducible zeolite $\mathrm{T}$ membranes from clear solutions

ZHANG Xiaoliang, SONG Xin, QIU Lingfang, DING Minzheng, HU Na, ZHOU Rongfei, CHEN Xiangshu* Jiangxi Normal University

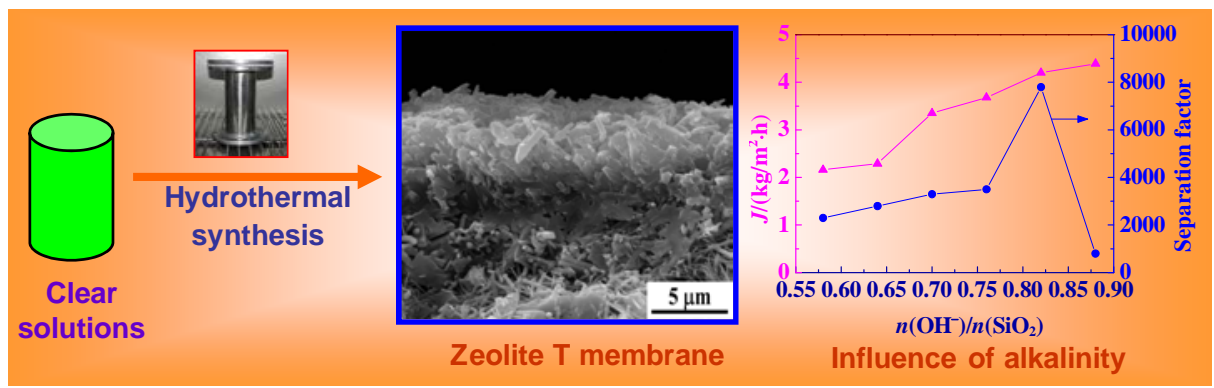

Highly reproducible zeolite T membranes were hydrothermally synthesized from clear solutions. Synthesis parameters, especially alkalinity, strongly affect the membrane growth and pervaporation performance.

[11] Zhou H, Li Y S, Zhu G Q, Liu J, Yang W S. Sep Purif Technol, 2009, 65: 164

[12] Zhou R F, Chen X Sh, Liu D, Qi H, Lin X, Xu N P.J Chin Ceram Soc (周 荣飞, 陈祥树, 刘丹, 漆虹, 林晓, 徐南平. 硅酸盐学报), 2007, 35: 1270

[13] Zhou R F, Hu N, Yuan H, Zhu M H, Wang Zh Zh, Chen X Sh.J Chin Inorg Chem (周荣飞, 胡娜, 袁慧, 朱美华, 王振卓, 陈祥树. 无机 化学学报), 2009, 25: 1439

[14] Zhou R F, Zhang F, Hu N, Chen X S, Kita H. Chem Lett, 2011, 40: 1383

[15] Zhang X L, Song X, Qiu L F, Zhou R F, Chen X Sh. Chin J Inorg Chem (张小亮, 宋金鎜, 邱灵芳, 周荣飞, 陈祥树. 无机化学学报), 2012, 28: 1914
[16] Breck D W, Acara N A. US Patent 2950952.1960

[17] Wang X Q, Chen Zh C, He Sh H, Mao Y G, Li Sh, Song T Y, Xu R R. Chem J Chin Univ (王杏乔, 陈忠财, 何淑华, 毛友刚, 李舒, 宋天佑, 徐如人. 高等学校化学学报), 1984, 5: 83

[18] Occelli M L, Innes R A, Pollack S S, Sanders J V. Zeolites, 1987, 7: 265

[19] Cichocki A. Zeolites, 1991, 11: 758

[20] Ueda S, Nishimura M, Koizumi M. Stud Surf Sci Catal, 1985, 24: 105

[21] Matin K T, Bastani D, Kazemian H. Chem Eng Technol, 2009, 32: 1042

[22] Mirfendereski M, Mohammadi T. Powder Technol, 2011, 206: 345

[23] Yu J H. Stud Surf Sci Catal, 2007, 168: 39

\section{清液体系中 $\mathrm{T}$ 型分子篮膜的高重复性合成与渗透汽化性能 \\ 张小亮, 宋 萃金, 邱灵芳, 丁民正, 胡 娜, 周荣飞, 陈祥树 ${ }^{*}$ 江西师范大学化学化工学院, 江西省无机膜材料工程技术研究中心, 江西南昌 330022}

摘要: 以自制微米级分子篮为晶种, 在清液体系中成功合成出高性能的 $\mathrm{T}$ 型分子篮膜, 考察了硅铝比、水硅比、碱度及合成温度与 时间等条件对膜的生长和渗透汽化性能的影响. 结果表明,在摩尔组成为 $1 \mathrm{SiO}_{2}: 0.015 \mathrm{Al}_{2} \mathrm{O}_{3}: 0.41\left(\mathrm{Na}_{2} \mathrm{O}+\mathrm{K}_{2} \mathrm{O}\right): 30 \mathrm{H}_{2} \mathrm{O}$ 的清液体系中, 于 $423 \mathrm{~K}$ 晶化 $6 \mathrm{~h}$ 的条件下可较快地形成一层厚度为 $5 \mu \mathrm{m}$ 的连续致密纯相 $\mathrm{T}$ 型分子笁膜, 较大缩短了膜合成时间且提高了膜致密 性. 在优化条件下所合成的膜具有优良的分离性能和高重复性. $348 \mathrm{~K}$ 时, 在 $10 \mathrm{wt} \%$ 水-90 wt\% 异丙醇混合物体系中膜的渗透通量 和分离因子分别高达 $4.20 \mathrm{~kg} /\left(\mathrm{m}^{2} \cdot \mathrm{h}\right)$ 和 7800 .

关键词: $\mathrm{T}$ 型分子節膜; 重复性; 清液; 二次生长法; 渗透汽化

收稿日期: 2012-09-05. 接受日期: 2012-10-12. 出版日期: 2013-03-20.

*通讯联系人. 电话: (0791)88120533; 传真: (0791)88120843; 电子信箱: cxs66cn@jxnu.edu.cn

基金来源：国家自然科学基金(20966003, 21106059); 国家高技术研究发展计划 (863 计划, 2012AA03A609); 江西省科技支撑计划 重点项目和自然科学基金(2010BGA01200, 2010GQH0068, 20122BAB203018); 江西省教育厅科技项目 (GJJ11377).

本文的英文电子版由Elsevier出版社在ScienceDirect上出版(http://www.sciencedirect.com/science/journal/18722067). 